\title{
Review on Rainfed Agriculture and Rainwater Harvesting Techniques
}

\author{
Ziye LIU \\ Class 16, 2014, Shahe No.1 Middle School, \\ Shahe, Hebei Province, 054100, China \\ e-mail: 1670867723@qq.com
}

\author{
Junying JIN \\ Department of Hydrology \& Water Resources, \\ Beibei, Chongqing, 400716, China \\ e-mail: junyingjin@126.com
}

\begin{abstract}
This paper summarizes the importance of water resource and more and more serious situations facing agricultural water use. Rainfed agriculture is a necessary way for crop production and food security. As one of the most efficient tool, rainwater harvesting can supplement rainfed agricultural and hence enhance the productivity. However, more comprehensive understanding and multidisciplinary study are needed to improve the efficiency of rainwater harvesting.
\end{abstract}

Keywords-water resource management; rainfed agriculture; harvesting

\section{INTRODUCTION}

Worldwide, water resources management has been undergoing changes due to population growth, urbanization and economic development; the issue of climate change adds a new dimension to the ongoing dynamics of water supply and demand. Reductions in rainfall have been observed in the lower tropical latitudes[1]. Some experts are predicting further declines in rainfall and amplification of extreme events[2].

Rainfed agriculture plays and will continue to play a dominant role in providing food and livelihoods in the world with an ever increasing population. How to improve in-situ rainwater use and hence reduce the agricultural risk is an important task nowadays. Rainwater harvesting has been practiced for many years in many areas of the world, especially, in arid and semi-arid regions like the Loess Plateau, North America, Middle-East, sub-Saharan Africa etc.

\section{IMPORTANCE OF RAINFED AGRICULTURE}

Rainfed crop production, which uses infiltrated rainfall that forms soil moisture in the root zone (the so-called green water resource), accounts for most of the crop water consumption in agriculture[3]. In the dry sub-humid and the semi-arid zones, where farming systems have experienced the lowest yields and the weakest yield improvements during the past decades[4], dry spell mitigation is a common water management practice for minimizing the risk of crop failure due to drought.

\section{A. Rainfed Agricultural in Different Climate and Its Crop Yield}

In the semi-arid and dry sub-humid zone, it is not the amount of rainfall that is the limiting factor of production
(Fig. 1) [5]. Rather, it is the extreme variability of rainfall, with high rainfall intensities, few rain events, and poor spatial and temporal distribution of rainfall.

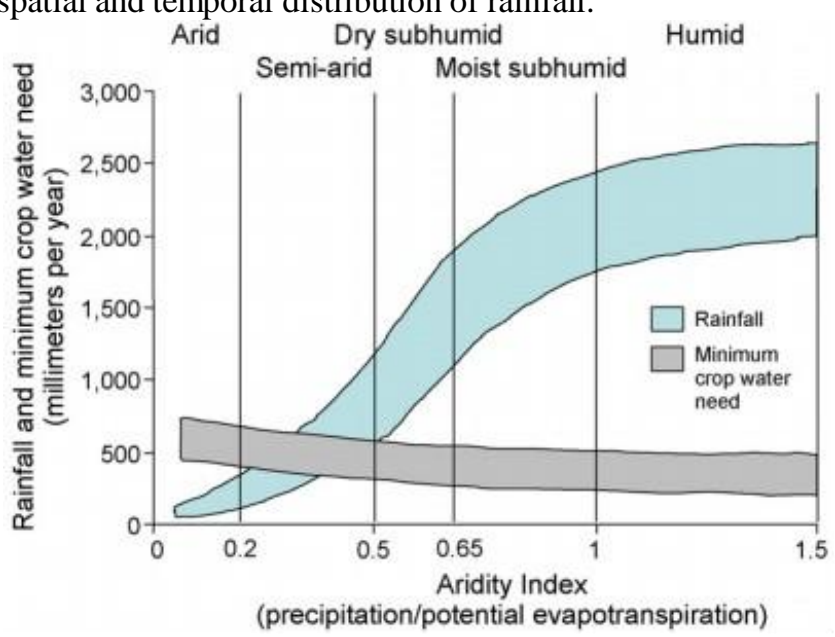

Figure 1. Range of rainfall variability across hydro-climatic zones from arid to humid agro-ecosystems. (The ecosystem gradient is shown as the aridity index (ratio of annual precipitation to annual potential evapotranspiration). The range in total rainfall is expressed as plus or minus one standard deviation. Minimum crop water needs from Doorenbos and Pruitt (1992) and adjusted for aridity index)

Farming systems often suffer from agricultural droughts and dry spells caused by management induced water scarcity[6]. Thus, crop failures commonly blamed on "drought," might be prevented in many cases through better farm-level water management. To address the challenge of obtaining the highest yield under variable rainfall conditions, interdisciplinary approaches are required: (1) to increase the amount of water made available to crops to satisfy their requirements over time with improved water management through rainwater harvesting $(\mathrm{RWH}) ;(2)$ to maximize water infiltration and holding capacity of soils coupled with improved soil management through conservation tillage, mulching, etc. and; (3) to increase crop access to water with improved crop management through selection of crop species, planting date, etc.[7]. The best strategy is to combine the various techniques and practices to obtain the highest yield (intersection of the three circles, Fig. 2) and, often it is an iterative process to achieve this combination. 


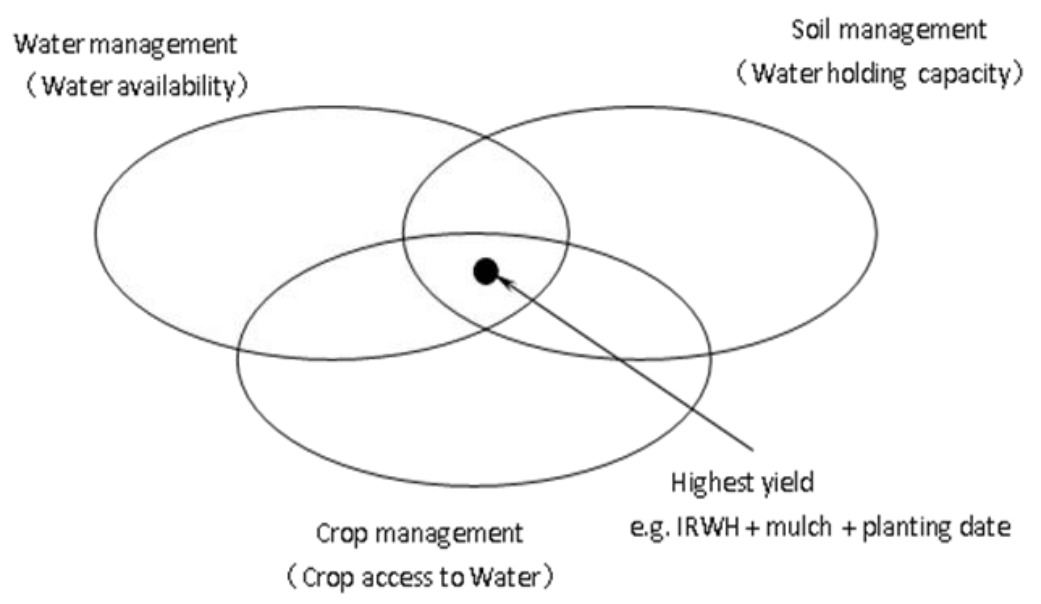

Figure 2. Integrated Water-soil-crop management strategies (FAO, 2008)

\section{B. The Rainwater Harvesting Theory and Techniques}

The frequently advocated approach to enhance water productivity in smallholder rain-fed agriculture is to adopt water harvesting and conservation technologies (WH). Among the most common soil and water conservation techniques, rainwater harvesting (RWH) is massively promoted by NGOs, national agricultural extension services and government agencies in African countries[8], as well as in India where RWH practices already have a long tradition ${ }^{9}$. A number of scholars have confirmed the potential of RWH to enhance water productivity by mitigating temporal and spatial variability of rainfall[6,7,10,11,12]. Rainwater harvesting is also one of the practices recommended by UNCCD to combat desertification. Its implementation is promoted to alleviate temporal and spatial water scarcity for domestic, crop and livestock production and support the overall water resources management [7].

Soil and water conservation, or in-situ water harvesting, has been the focus of most of the investment in water management in rainfed agriculture during the past 50 years. Since in-situ water harvesting can be applied on any piece of land and is affordable to most smallholder farmers. Rainwater harvesting in the broad sense describes all methods for concentrating, storing and collecting runoff from rainwater, for domestic and agricultural uses[13]. The key function of RWH is to alter the partitioning of precipitation into less surface runoff and more soil moisture; and partition more of the soil moisture into crop transpiration and less to soil evaporation[14]. These water harvesting systems can be grouped into three main types, namely; in-situ moisture conservation (soil and water conservation), concentration of runoff to crops in the field, and collection and storage of runoff water (from roofs and land areas) in different structures for both domestic and agricultural use[15].

Design and management of water harvesting systems may be conducted by models for soil water balance. One of these models is a simple, few parameters simulation model for a water harvesting strip farming systems. Sepaskhah \& Fooladmand[16] used a computer simulation model for design of microcatchment water harvesting systems for rainfed vineyard in Bagjah area of the Islamic Republic of Iran. The model includes rainfall, runoff, actual evapotranspiration, water contribution from deeper layers and deep percolation. Through the simulation, the study gave the suggestions of the microcatchment areas according to the probabilities of occurrence of annual rainfall. However, the study did not consider collecting the runoff for later use during dry spell. Sharma et al[17] estimated the efficiency of regional rain water use and incremental production due to supplementary irrigation for different crops. They concluded that "water harvesting and supplemental irrigation are economically viable at the national level. Net benefits improved by about threefold for rice, fourfold for pulses and sixfold for oilseeds. Droughts have very mild impacts on productivity when farmers are equipped with supplemental irrigation.".

Water harvesting for crop production, if successfully implemented with a social and hydrological catchment, will have many interacting implications on biophysical, economic, and ecological systems. It is suggested that water harvesting can never be an isolated effort within a farming system, and should rather be seen as a catalyst to improvement and modernization of production systems. The main entry point is suggested to be the possibility of reducing crop failure, which in turn can function as incentive to invest in seed variety, fertilizer application to further improve crop production.

\section{CONCLUSIONS}

There is a growing scarcity of and competition for water among agricultural, industrial, commercial, and residential sectors forcing water resources management to allocate water more efficiently. In semi-arid and sub-humid regions, wherever rainfed agriculture is practiced, agricultural drought is a common problem. In order to improve crop water productivity and at the same time reduce the risk of rainfed agriculture, RWH potential assessment is necessary. It asks the clear understanding of soil hydrological properties, its spatial and temporal variation and affecting factors. These properties can be measured and monitored in field and indoors. GIS and hydrological models can be integrated to 
simulate the rainfall-runoff process and hence estimate the RWH potential. By balance the crop water requirement, available rainfall and soil moisture, the crop water deficit can be calculated. Small scale storage works can be the best choice for supplementary irrigation in hilly areas.

\section{ACKNOWLEDGMENTS}

The research was financially supported by Chongqing foundation and advanced research program (No.cstc2016jcyjA0460), and the support was gratefully acknowledged.

\section{REFERENCES}

[1] X. Zhang, F.W. Zwiers, G.C. Hegerl, F.H.Lambert, N.P.Gillett, S.Solomon, P.A.Stott, T. Nozawa. Detection of human influence on twentieth-century precipitation trends. Nature 448, 461-466 (2007).

[2] IPCC (Intergovernmental Panel on Climate Change), Climate Change 2007. Fourth Assessment Report. Cambridge University Press, (Cambridge, UK., 2007).

[3] J. Rockstrom, L.Karlberg, S.P. Wani, J. Barron, N. Hatibu, T. Oweis, A. Bruggeman, J. Farahani, Q. Zhu. Managing water in rainfed agriculture-The need for a paradigm shift. Agricultural Water Management, 97: 543-550 (2010)

[4] FAOSTAT, Database. Food and Agriculture Organization, Rome (2005) . http://faos-tat.fao.org/.

[5] A. Agarwal. Drought? Try capturing the rain. Briefing Paper. Centre for Science and Environment, New Delhi (2000).

[6] J. Rockstrom, J. Barron. Water productivity in rainfed systems: overview of challenges and analysis of opportunities in water scarcity prone savannahs. Irrigation Science, 25(3): 299-311 (2007).

[7] J. Mwenge Kahinda, A.E. Taibenu, B.B.P. Sejamoholo, E.S.B. Lillie, R.J. Boroto, A GIS-based decision support system for rainwater harvesting (RHADESS). Physics and Chemistry of the Earth, 34: 767775(2009).
[8] L. Stroosnijder, Technologies for improving rain water use efficiency in semi-arid Africa. In: Proceedings of the Symposium and Workshop on Water Conservation Technologies for Sustainable Dryland Agriculture in Sub-Saharan Africa, (Bloemfontein, South Africa, 2003). PP. 60-74.

[9] D.N.Pandey, A.K. Gupta, D.M. Anderson. Rainwater harvesting as an adaptation to climate change. Current Science, 85: 46-59(2003).

[10] H. Makurira, H. H. G. Savenije, S. Uhlenbrook, J. Rockstrom, and A. Senzanje. Investigating the water balance of on-farm techniques for improved crop productivity in rainfed systems: A case study of Makanya catchment, Tanzania. Physics and Chemistry of the Earth, 34:93-98(2009).

[11] Ngigi, S.N.. Hydrological impacts of land use changes on water resources management and socio-economic development of upper Ewaso Ng'iro river basin in Kenya. $\mathrm{PhD}$ thesis, UNESCOIHE/Technical University of Delft, Netherlands. AA Balkema Publishers, (The Hague, 2006).

[12] T. Oweis, A. Hachum. Water harvesting and supplemental irrigation for improved water productivity of dry farming systems in West Asia and North Africa. Agricultural Water Management, , 80: 57-73(2006).

[13] D.C. Sutherland, C.R.Fenn. Assessment of water supply options. Prepared for the World Commission on Dams (Cape Town, 2000).

[14] J.C.M.Andersson, A.J.B.Zehnder, G.P.W. Jewitt, H. Yang. Water availability, demand and reliability of in situ water harvesting in smallholder rain-fed agriculture in the Thukela River Basin, South Africa. Hydrology and Earth System Sciences. 13: 2329-2347 (2009).

[15] M.Falkenmark, J. Rockstrom,. Balancing water for humans and nature: The new approach in ecohydrology. (London, UK: Earthscan, 2004).

[16] A.R.Sepaskhah, H.R.Fooladmand. A computer model for design of microcatchment water harvesting systems for rain-fed vineyard. Agricultural Water Management, 64: 213-232 (2004).

[17] B. R.Sharma, K.V.Rao, K.P.R.Vittal, Y.S.Ramakrishna, U. Amarasinghe. Estimating the potential of rainfed agriculture in India: Prospects for water productivity improvements. Agricultural water management, 97: 23-30(2010) 